\title{
Histopathological spectrum of Cervical Lesion"- two and half Year prospective Study in Tertiary Care Center of Chhattisgarh, India
}

\author{
Kujur P. ${ }^{1}$, Indoria C. ${ }^{2 *}$, Bagde S. ${ }^{3}$, Tiwari A. ${ }^{4}$ \\ DOI: https://doi.org/10.17511/jopm.2021.i02.01 \\ 1 Pratima Kujur, Professor, Department of Pathology, BRLSABVM Government Medical College, Rajnandgaon, Chhattisgarh, India. \\ 2* Chandrashekhar Indoria, Assistant Professor, Department of Pathology, BRLSABVM Government Medical College, Rajnandgaon, \\ Chhattisgarh, India. \\ ${ }^{3}$ S. Bagde, Associate Professor, Department of Pathology, BRLSABVM Government Medical College, Rajnandgaon, Chhattisgarh, India. \\ ${ }^{4}$ A. Tiwari, Assistant Professor, Department of Pathology, BRLSABVM Government Medical College, Rajnandgaon, Chhattisgarh, India.
}

Introduction: Cervical lesions are the leading cause of morbidity in Indian women and cervical cancer is the second most common cancer in women worldwide next to breast cancer. Objectives: To study the age distribution, the relative frequency of various cervical lesions and histopathological features of cervical lesions. Materials and Methods: This is a two \& half years retrospective study of all cervical biopsies and hysterectomy specimens received from September 2017 to March 2020 in the department of pathology. Result: In a total of 485 cases studied 359 (74.1\%) cases were nonneoplastic, $107(22 \%)$ were preinvasive and $19(3.9 \%)$ cases were malignant. Cervicitis was the most common non-neoplastic lesion and squamous cell carcinoma was the most common cancer. Conclusion: Our study highlights a vast spectrum of cervical lesions and therefore early detection and management of certain lesions can help in reducing morbidity.

Keywords: Cervical lesions, Histology and pathology, Carcinoma cervix

\section{Corresponding Author}

Chandrashekhar Indoria, Assistant Professor, Department of Pathology, BRLSABVM Government Medical College, Rajnandgaon, Chhattisgarh, India. Email: dr.csindoria@gmail.com
How to Cite this Article

To Browse

Kujur $\mathrm{P}$, Indoria $\mathrm{C}$, Bagde $\mathrm{S}$, Tiwari A. Histopathological spectrum of Cervical Lesion"- two and half Year prospective Study in Tertiary Care Center of Chhattisgarh, India. Trop J Pathol Microbiol. 2021;7(2):65-70.

Available From

https://pathology.medresearch.in/index.php/jopm/ar

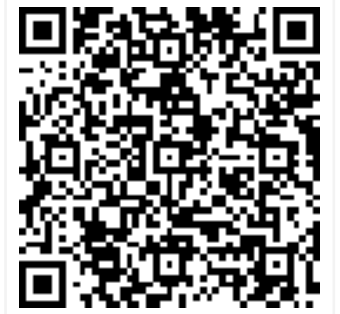
ticle/view/487 


\section{Introduction}

Worldwide, Cervical cancer was the fourth most common cancer in women, contributing $6.9 \%$ of the total number of new cases diagnosed in 2018. [1] In India, Carcinoma of the cervix is the most common cancer in Indian women and account for $22.86 \%$ of all malignant tumours in women. Cervical cancer is the third largest cause of cancer mortality in India accounting for nearly $10 \%$ of all cancer-related deaths in the country.[1]

Non-neoplastic cervical lesions occur in all age groups amongst women but are more common in reproductive and sexually active women.[2] Nonneoplastic cervical lesions include inflammatory lesions and non-neoplastic tumour-like lesions. The majority of these inflammatory lesions are acute cervicitis, chronic cervicitis caused by various bacteria, viruses and fungi.[2] Cervicitis caused by the Human papillomavirus carries a high risk for Condyloma acuminata, Cervical intraepithelial neoplasia (CIN) and carcinoma.[3] Cervical carcinomas are classified by WHO classification which is widely accepted.[4]

The predominant risk factor of carcinoma cervix is a persistent human papillomavirus infection. Other risk factors are lack of awareness, early age at marriage, low socioeconomic status, parity, race and tobacco smoking. Prognosis depends mainly on the stage of the disease.

This study was undertaken to observe the histomorphological distribution of cervical lesion in our tertiary care centre.

\section{Material Methods}

Setting: The study has been carried out in the Department of Pathology, Bharat Ratna Late Atal Bihari Vajpayee Memorial Govt Medical College, Rajnandgaon (Chhattisgarh).

Duration and type of study: a prospective study over two and a half years from September 2017 to March 2020

Sampling methods: In this study we included 485 patients irrespective of their age, religion who attended the hospital and brief history including chief complaints, obstetric history and relevant history were taken and cervical biopsies or hysterectomy specimen were sent for histopathological confirmation to the department of pathology.

\section{Sample size calculation:-}

Sample size $(\mathbf{n})=(\underline{Z 1-a / 2}) \underline{2 *}(\underline{p})(\underline{q})$.

(D)2

$\mathrm{N}=$ Desired sample size

(Z 1-a/ 2) 2 = Critical value and a standard value for the corresponding level of confidence

(At $95 \%$ CI or $5 \%$ level of significance (type-I error) it is 1.96 and at $99 \% \mathrm{CI}$ it is 2.58 )

$\mathrm{P}=$ Expected prevalence or based on previous research

$\mathrm{Q}=1-\mathrm{p}$

$D=$ Margin of error or precision

A previous study stated that cervical lesion in the adult population was $40 \%$. At $95 \%$ CI and $5 \%$ margin of error. On applying the above formula,

$(N)=388.79,(n)=388+77$ (considering 20\% drop out of study participants) +20 sample had taken additionally to minimize error $=485$.

Statistical Analysis: Data was entered in an Excel sheet and values were obtained by frequency, proportion and chi-square test.

\section{Result}

During the period of the present study total of 485 specimens received from the department of gynaecology were processed and reported. 95 cervical biopsies and 390 hysterectomy specimen were received. Out of 485 cases, 359 (74.1\%) were reported as non-neoplastic lesions, 107(22\%) were reported as preinvasive intraepithelial changes, and $19(3.9 \%)$ were reported as a neoplastic lesion (Table1).

Out of 359 non-neoplastic lesions, 267(55.2\%) were cervicitis, $57(11.6 \%)$ were nabothian cyst and 33 $(6.8 \%)$ were endocervical polyp (table 2 ). The most common preinvasive intraepithelial lesion was CIN-I changes (74.7\%). Among 19 neoplastic lesions the most common malignancy was squamous cell carcinoma comprised of $84.2 \%$ followed by adenosquamous carcinoma.

Table-1: Age distribution of patients with cervical lesion

\begin{tabular}{|l|l|l|}
\hline \multicolumn{1}{|c|}{ Age in years } & \multicolumn{1}{c|}{ Frequency } & \multicolumn{1}{c|}{ Percentage } \\
\hline $21-30$ & 6 & 1.2 \\
\hline $31-40$ & 152 & 31.3 \\
\hline
\end{tabular}




\begin{tabular}{|l|l|l|}
\hline $41-50$ & 207 & 42.6 \\
\hline $51-60$ & 83 & 17.2 \\
\hline $61-70$ & 36 & 7.5 \\
\hline$>70$ & 1 & 0.2 \\
\hline
\end{tabular}

Table-2: Distribution of types of Cervical lesion

\begin{tabular}{|l|l|l|}
\hline \multicolumn{1}{|c|}{ Cervical lesion } & \multicolumn{1}{c|}{ Frequency } & \multicolumn{1}{c|}{ Percentage (\%) } \\
\hline Non neoplastic & 359 & 74.1 \\
\hline Preinvasive & 107 & 22 \\
\hline Malignant & 19 & 3.9 \\
\hline Total & 485 & 100 \\
\hline
\end{tabular}

Table-3: Histological types of cervical lesions

\begin{tabular}{|l|l|l|}
\hline \multicolumn{1}{|c|}{ Histological diagnosis } & Frequency & Percentage \\
\hline Chronic non-specific cervicitis & 267 & 55.2 \\
\hline Granulomatous cervicitis & 2 & 0.5 \\
\hline Nabothian cyst & 57 & 11.6 \\
\hline Endocervical polyp & 33 & 6.8 \\
\hline CIN -I Changes & 80 & 16.5 \\
\hline CIN -II Changes & 15 & 3 \\
\hline CIN -III Changes & 10 & 2 \\
\hline Carcinoma in situ & 2 & 0.4 \\
\hline Squamous cell carcinoma & 16 & 3.3 \\
\hline Adenosquamous carcinoma & 2 & 0.5 \\
\hline Adenocarcinoma & 1 & 0.2 \\
\hline
\end{tabular}

\section{Discussion}

In our study the most common age group affected was $41-50$ years $(42.6 \%)$ (Table-1). This age range was comparable with the study done by Krishnappa et al [5], Pradhan et al.,[6] Shruthi et al., [7] Fotra et al., [8] Sinha et al., [9] and Jashamy KA et al. [10]

The present study shows Non-neoplastic lesions $(74.1 \%)$ are more common than malignant lesions in the Rajnandgaon region which was similar to the studies done by Avani J et al [22] and Srivani S et al [2] in which non-neoplastic lesion were $73 \%$ and $79.7 \%$ respectively. But on the contrary the study done by Ali EF et al., showed malignant condition $(51.2 \%)$ were more common than Non-neoplastic (46.34\%) [28].

Among non-neoplastic lesion we found that the Chronic non-specific cervicitis accounted highest percentage $(55.2 \%$ cases) (Table- 3 ), it could be due to poor personal hygiene, a lack of health awareness and early marriage in the rural Rajnandgaon region. Chronic non-specific cervicitis accounts for the majority of disease burden in this study compared to the study done by Kiranmayi et al [11], Badge et al [12].
A similar finding is also noted by Nwachokor et al [13] and kumari $\mathrm{k}$ et al.[20]. Causative organisms for cervicitis include various organisms like, bacterial, viral, protozoan \& fungi.[11] Granulomatous lesions most commonly occur due to Mycobacterium tuberculosis infection and had a very low incidence of $1.98 \%$. [14, 15] .In our study two lesions presented as the bulky cervix, was diagnosed with granulomatous cervicitis in histopathology and further microbiological ancillary tests established the cause as Mycobacterium tuberculosis.

Non-neoplastic tumours like lesions such as polyps (endocervical and leiomyomatous) were seen in $6.8 \%$ of cases. It was comparable to studies done by Saravana et al [2], Nwachokor et al [13] and Bansal A et al [17] while it was significantly higher than in a study by Hatwal et al. [16] (1.08\%). The present study showed one rare case of hamartomatous endocervical polyp aged 42 years female.

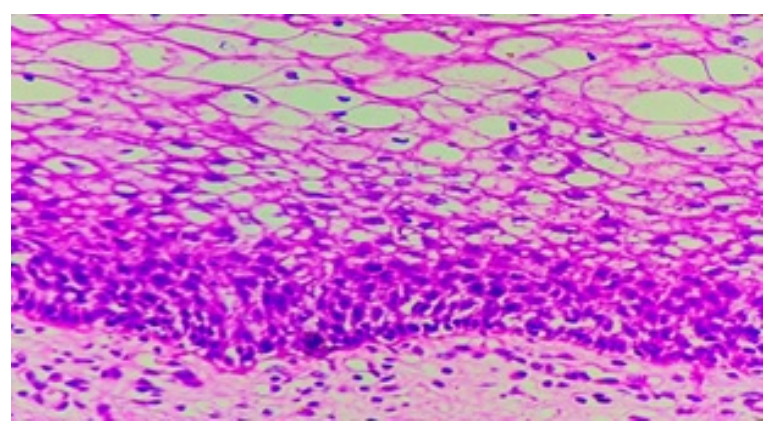

Figure 1:-CIN-I Changes

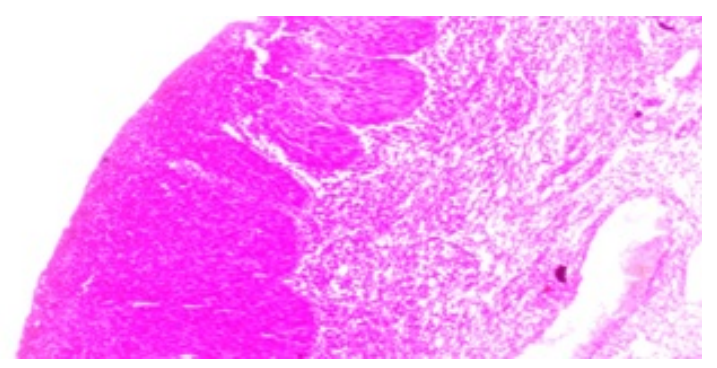

Figure 2:-CIN-III Changes

In our study the incidence of the preinvasive lesion was $22 \%$ ( table-2). Kirammyi et al [9] found a $15.11 \%$ preinvasive lesion in his study. In the present study Incidence of CIN-I (16\%) was more compared to CIN-II and CIN-III in this study (Table3 ), similarly Badge et al [12] found CIN I in $16.14 \%$ and CIN II in $10.25 \%$ and Thapa et al [18] found CIN I in $18.06 \%$, CIN II in $20.93 \%$. 


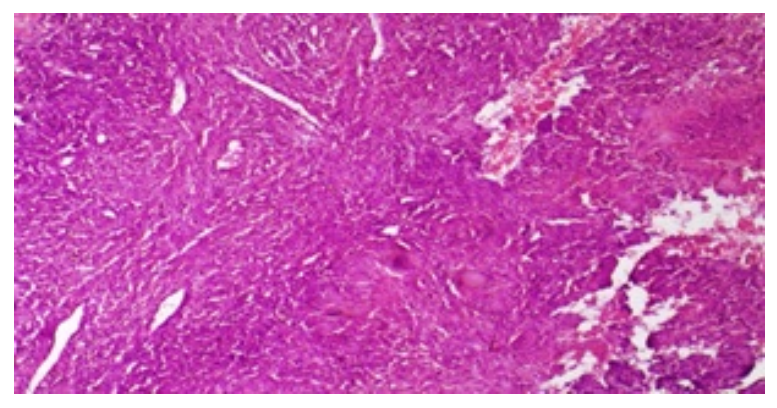

Figure 3:- Granulomatous Cervicitis

Malignant lesions comprise 19 (3.9\%) and findings were lower than the results obtained by Avani $\mathrm{J}$ et al [22] and Srivani $S$ et al [2] in which neoplastic lesion was $5.5 \%$ and $9.6 \%$ respectively. Among invasive neoplasms Squamous cell carcinoma, was most common accounting for $84.2 \%$, followed by adenosquamous carcinoma (10.5\%) and adenocarcinoma $(0.5 \%)$.

The distribution of these 3 tumours in this study is similar to the study done by Shingleton et al. [24] and closely comparable to the studies were done by Jeong et al., [26] Alfsen et al.,[21] and Galic et al. [27] It was observed that in all studies compared SCC was the most common tumour. Adenosquamous carcinoma of the cervix is rare.

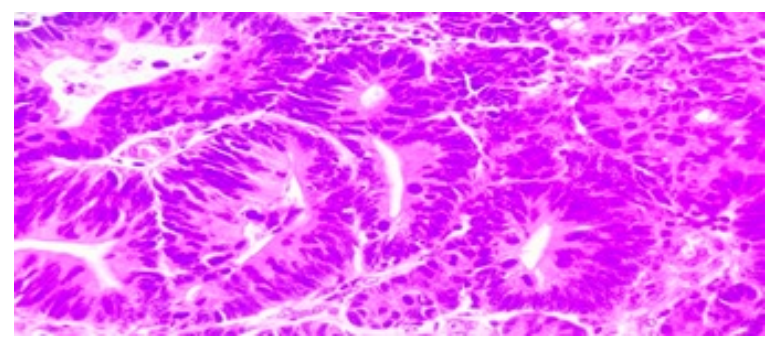

\section{Figure 4:-Adenocarcinoma Cervix}

It is defined as having both glandular and squamous cell differentiation, each component malignant. The present study, reported two cases of Adenosquamous Carcinoma aged 72 years and 66 years females. [fig 04].

The present study shows Non-neoplastic lesions were more common than malignant lesion followed by Preinvasive lesion. Chronic cervicitis was the major inflammatory lesions and Squamous Cell Carcinoma was the most common malignant lesions.Authors came across less number of cases of malignancy compared to other studies because this is a tribal rural area where fewer people come to the hospital and in an advanced stage or referred to higher centres for further treatment.
People usually treat chronic conditions indigenously at their home.

\section{Limitation}

The present study revealed a wide spectrum of cervical lesions in a small study population. Followup could not be done in cases of malignant lesions as they are referred to the higher centre. In this study, Low-Grade Squamous Intraepithelial Lesions could not be followed up with HPV DNA testing and HSIL with LEEP, conization because of their unavailability in our setup and high cost.

\section{Conclusion}

01 . This study demonstrated that inflammatory lesions were the most common non-neoplastic cervical lesion followed by the preinvasive lesion.

02. In our region of Chhattisgarh Squamous cell carcinoma was most common among cervical malignancy.

03. The present study found two rare cases one was Hammartomatous cervical polyp and another was Adenosquamous carcinoma.

04. This study highlights a vast spectrum of cervical lesions and therefore early detection and management of certain lesions can help in reducing the morbidity.

05. Histopathological diagnosis regarded as the "gold standard" and clinical management and follow up are often based on it.

\section{What does this study add to existing knowledge?}

Authors came across less number of cases of malignancy compared to other studies because this is a tribal rural area where fewer people come to the hospital and in an advanced stage or referred to higher centres for further treatment.

\section{Reference}

01. Bray F, Ferlay J, Soerjomataram I, Siegel RL, Torre LA, Jemal A. Global Cancer Statistics 2018- GLOBOCAN estimates of incidence and mortality worldwide for 36 cancers in 185 countries. CA Cancer J Clin, in press. 2018. accessible at as part of IARC's Global Cancer Observatory [Article] [Crossref] 
02. Srivani Saravanan, Jonathan Arnold, Arul P. "Histomorphological Spectrum of Lesions of the Cervix, A Retrospective Study in a Tertiary Care Hospital". Journal of Evolution of Medical and Dental Sciences. 2015; July 4(59)10326-10329. [Crossref]

03. Bosch FX, Lorincz A, Muñoz N, Meijer CJ, Shah $\mathrm{KV}$. The causal relation between human papillomavirus and cervical cancer. J Clin Pathol. 2002 Apr;55(4)244-65.

[Crossref]

04. Fritz A, Percy C, Jack A, Shanmugaratnam K, Sobin LH, Parkin DM, Whelan S. International classification of Diseases for oncology (ICD-0). 3rd edition, World health organization- Geneva. 2000.

[Crossref]

05. Krishnappa C, Kanabur DR, Dinesh CU. Clinicomorphological Spectrum of Neoplasms of Uterine Cervix in a Tertiary Care Center in North Karnataka, South India. Int J Sci Stud. 2016;4(2)6-12.

[Crossref]

06. Pradhan B, Pradhan SB, Mital VP. Correlation of PAP smear findings with clinical findings and cervical biopsy. Kathmandu Univ Med J (KUMJ). 2007;5;461-7.

[Crossref]

07. Shruthi PS, Kalyani R, Kai LJ, Narayanaswamy M. Clinicopathological correlation of cervical carcinoma- A tertiary hospital based study. Asian Pac J Cancer Prev. 2014;15;1671-74. [Crossref]

08. Fotra R, Gupta S, Gupta S. Sociodemographic risk factors for cervical cancer in Jammu region of $\mathrm{J}$ and $\mathrm{K}$ state of India first ever report from Jammu. Indian J Sci Res. 2014;9:105-10.

[Crossref]

09. Sinha $P$, Rekha PR, Subramaniam PM, Konapur PG, Thamilselvi R, Jyothi BL. A Clinicomorphological study of carcinoma cervix. Nat J Basic Med Sci. 2011;2;2-7.

[Crossref]

10. Jashamy KA, Al-Naggar RA, San P, Mashani M. Histopathological findings for cervical lesions in Malaysian women. Asian Pac J Cancer Prev. 2009;10;1159-62.

[Crossref]
11. BVVD Kiranmayi. "Morphological Spectrum of Cervical lesions with an emphasis on Neoplastic lesions - a 2year retrospective study". IOSR Journal of Dental and Medical Sciences (IOSRJDMS). 2017;16(11)54-57.

[Crossref]

12. Bagde, Gupta R, Ganguly S, Bhardwaj A, Jogis. "Spectrum of Cervical Lesions in CIMS, BilaspurA 5 years Retrospective Study of 215 Cases in a Tertiary Hospital of Central India". Journal of Evidence based Medicine and Healthcare. 20150ct-19;2(42)7505-7510.

[Crossref]

13. Nwachokor FN, Forae GC. Morphological spectrum of non-neoplastic lesions of the uterine cervix in Warri, south-south, Nigeria. Niger J ClinPract. 2013 Oct-Dec;16(4)429-32. doi: 10.4103/1119-3077.116883 [Crossref]

14. Richards MJ, Angus D. Possible sexual transmission of genitourinary tuberculosis. Int $\mathrm{J}$ Tuberc Lung Dis. 1998;2;439.

[Crossref]

15. oussa $B$, valentine $K$,Adama O,Aziz D A, Idrissa $Z$, Goumburi LO. Tuberculosis of the Uterine Cervix- About a Case and Literature Review. Open Journal of Obstetrics and Gynecology. 2016;6;734-739.

[Crossref]

16. Hatwal D, Batra N, Kumar A, Chaudhari S, Bhatt S. Spectrum of Nonneoplastic Lesions of Uterine Cervix in Uttarakhand. National Journal of Laboratory Medicine. 2016;1-5.

DOI: NJLM/2016/18005:2098 [Crossref]

17. Bansal A, Kumar A, Reddy GT. Benign lesions of cervix uteri- without human papilloma virus. International Journal of Research and Review. 2019;6(11)254-259.

[Crossref]

18. Tamboli GD, Khatod LV. Accuracy of cytological findings in abnormal cervical smear by cytohistological comparision. J Medical Education Research. 2013;3(2)19-24.

[Crossref]

19. Saha R, Thapa M. Correlation of Cervical cytology with Cervical Histology. Kathmandu University Med J Kumj. 2015;3;222-4.

[Crossref] 
20. Kumari k, Umrani MK, bharathi $M$. Histopathological spectrum of cervical biopsiesa 5 year retrospective study. Trop J path micro. 2017;3(1)46-51.

doi: $10.17511 /$ jopm.2017.i1.08 [Crossref]

21. Alfsen GC, Kristensen GB, Skovlund E, Pettersen EO, Abeler VM. Histologic subtype has minor importance for overall survival in patients with adenocarcinoma of the uterine cervix- $A$ population-based study of prognostic factors in 505 patients with non squamous cell carcinomas of the cervix. Cancer. $2001 ; 92 ; 2471-83$.

[Crossref]

22. Jain A, Dhar R, Patro $P$, et al. Histopathological study of cervical lesions. Int J Health Sci Res. 2018;8(11)82-87.

[Crossref]

23. Krishna T, Gattu V. Study of spectrum of lesions of cervix in hysterectomy specimens. Sch J App Med Sci. Apr 2017; 5(4C):1443-1449.

[Crossref]
24. Shingleton HM, Bell MC, Fremgen A, Chmiel JS, Russell $A H$, Jones $W B$, et al. Is there really a difference in survival of women with squamous cell carcinoma, adenocarcinoma, and adenosquamous cell carcinoma of the cervix?. Cancer. $1995 ; 76 ; 1948-55$.

[Crossref]

25. Galic V, Herzog TJ, Lewin SN, Neugut AI, Burke WM, Lu YS, et al. Prognostic significance of adenocarcinoma histology in women with cervical cancer. Gynecol Oncol. 2012;125;28791.

[Crossref]

26. Jeong BK, Choi DH, Huh SJ, Park W, Bae DS, Kim BG. The role of squamous cell carcinoma antigen as a prognostic and predictive factor in carcinoma of uterine cervix. Radiat Oncol J. 2011;29;191-8.

[Crossref]

27. Bansal S, Lewin SN, Burke WM, Deutsch I, Sun $X$, Herzog TJ, Wright JD. Sarcoma of the cervix: natural history and outcomes. Gynecol Oncol. 2010 Aug $1 ; 118(2) 134-8$.

doi: 10.1016/j.ygyno.2010.04.021 [Crossref] 